Citation: Maria Raimondo, Concetta Nazzaro, Annamaria Nifo, Giuseppe Marotta (2020) Does the Institutional Quality Affect Labor Productivity in Italian Vineyard Farms?. Wine Economics and Policy 9(2): 113-126. doi: 10.36253/ wep-7833

Copyright: (c) 2020 Maria Raimondo, Concetta Nazzaro, Annamaria Nifo, Giuseppe Marotta. This is an open access, peer-reviewed article published by Firenze University Press (http:// www.fupress.com/wep) and distributed under the terms of the Creative Commons Attribution License, which permits unrestricted use, distribution, and reproduction in any medium, provided the original author and source are credited.

Data Availability Statement: All relevant data are within the paper and its Supporting Information files.

Competing Interests: The Author(s) declare(s) no conflict of interest.

\section{Does the Institutional Quality Affect Labor Productivity in Italian Vineyard Farms?}

\author{
Maria Raimondo ${ }^{1, *}$, Concetta Nazzaro ${ }^{4}$, Annamaria Nifo ${ }^{3}$, Giuseppe \\ MAROTTA $^{2}$ \\ ${ }^{1}$ Università degli Studi del Sannio, Department of Law, Economics, Management and \\ Quantitative Methods, Benevento, Italy,Email: raimondo@unisannio.it \\ ${ }^{2}$ Università degli Studi del Sannio, Department of Law, Economics, Management and \\ Quantitative Methods, Benevento, Italy,Email: marotta@unisannio.it \\ ${ }^{3}$ Università degli Studi del Sannio, Department of Law, Economics, Management and \\ Quantitative Methods, Benevento, Italy,Email: nifo@unisannio.it \\ ${ }^{4}$ Università degli Studi del Sannio, Department of Law, Economics, Management and \\ Quantitative Methods, Benevento, Italy,Email: cnazzaro@unisannio.it \\ ${ }^{\star}$ Corresponding author
}

\begin{abstract}
The paper aims at analyzing the effect of institutional quality on labor productivity in the agricultural sector. To meet this aim, a Gaussian log-linear model was applied to 773 vineyard farms, located in 71 Italian provinces. The applied methodology enabled to quantify the overall impact of the institutional quality on labor productivity by discriminating with respect to the Italian regions and macro-areas (i.e. North, South or Central Italy). The findings of the investigation show a positive effect of the institutional quality on labor productivity, with an overall impact of $39 \%$. Moreover, huge differences among Italian regions and macro-areas were detected. The study findings provide recommendations for academics and policy-makers to improve both theoretical and practical aspects.
\end{abstract}

Keywords: IQI, labor productivity, vineyard farm.

\section{INTRODUCTION}

In the last decades, institutional factors have attracted great interest as one of the main determinants of economic performance of countries and regions $[1,2,3,4]$. A large literature has emphasized the role of institutions in influencing both inputs (physical and human capital) and productivity, thus focusing on the existence of an additional effect of institutions on the per capita Gross Domestic Products (through productivity changes). Previous studies have also emphasized the role of institutions into influencing the ability of firms to combine inputs more efficiently $[5,6,7]$. Often, a positive and important of context factor is also recognized in the good institutional quality of the geographical area where the firm is located. Such a quality may be defined as a fruitful combination of formal institutions, good rules and 
practices, cooperation among firms, researchers and policy makers $[8,9,7,10]$.

In this vein, institutions shape the key incentives of individuals and firms, influencing investments in physical capital, human capital, technology and the ability to organize production, determining not only the potential for aggregate economic growth, but also the distribution of resources $[11,12,13]$. As for the agricultural sector, some authors have theoretically analyzed the effect of institutional context on economic performances of farms [14]. However, few researches have empirically investigated the effect of institutional quality on farm's economic performances $[15,13,16]$. Accordingly, the general goal of this study is to empirically investigate the effect of institutional quality on economic performances of Italian farms. In particular, since better institutions create a legal structure which increases: i) the adoption of technological innovation [17], ii) the likelihood that a firm conducts and transfer R\&D activities [18] and iii) the human development [19], the research hypothesis is that the institutional quality positively affects labor productivity in Italian vineyard farms. Precisely, by taking Italian farms specialized in viticulture (wine of excellence) as a case study, the specific goals of the present study are to: i) investigate the effect of the institutional quality on labor productivity, ii) quantify the effect of institutional quality on labor productivity, and finally, iii) assess the effect of institutional quality on labor productivity among Italian regions and macro-areas (North, Center and South).

Italian vineyard farms have been chosen for the following reasons: i) Italy is one of the main wine producing and wine-exporting country in the world $[20,21$, 22]. In fact, in 2016, Italy has produced more than 50 million $\mathrm{hL}$ of wine, the highest in the world. [23] Currently it counts more than 600.000 hectares of vineyards and around 350 autochthonous grape varieties, 470 protected designation of origin (PDO) wines and 120 protected geographical indication (PGI) wines [24]; ii) viticulture is widely spread in all Italian regions; iii) during the last decade, the labor productivity in Italian viticulture is gaining attention by strengthening the mechanization along the production process [25, 22].

For the purposes of the present paper, we refer to the Farm Accountancy Data Network (FADN), a dataset which records information about statistically representative aspects of farms and farmers, referred to 2012. As for the institutional quality, we have accounted for the Institutional Quality Index (IQI) developed by Nifo and Vecchione [9]), which regards institutional quality in Italian provinces as a composite indicator derived by 24 elementary indexes grouped into five institutional dimensions (namely corruption, government effectiveness, regulatory quality, rule of law, voice and accountability).

The investigation is conducted on a sample of 773 Italian vineyard farms, located in 71 of the overall 107 Italian provinces. Given the nature of the data, a Gaussian log-linear model is performed.

The paper is organized as follows: paragraph 2 outlines the theoretical framework; paragraph 3 illustrates the statistical model once described the materials of the study. Then, the study findings are exploited in paragraph 4 , and discussed in paragraph 5 . Conclusions and implications are drawn in paragraph 6.

\section{THEORETICAL BACKGROUND}

The decisive impact that institutions may have on economic growth, on the environment, on service levelof-quality, and on overall efficiency of an area has been examined by a broad strand of the economics literature that, in recent years, has paid growing attention to the role of political and administrative contexts as well as social, historical and cultural factors in conditioning and steering development processes. Starting from the work of Douglass North [1, p. 3], according to whom "institutions are the rules of the game in a society", institutions contribute to forming the set of incentives underlying behavior and individual choices. As a consequence, several studies have been concerned with measuring the quality of political and administrative institutions (in terms, for example, of well-defined property rights, respect for regulations, degree of corruption, and barriers to entry on markets) both for cross-country [26, 27, 28, $29,30,31,32,33]$ and inter-regional comparisons [34, 35, $36,37]$. Several researches $[6,38,39,40]$ have specifically focused on the importance of institutional quality as the basic determinant of economic growth and total productivity of factors in the long term. The institutional differences as a key factor of growth and stagnation as well as disparities in productivity and accumulation of physical and human capital is also investigated [11]. Some authors have focused on the role of sub-national institutions, particularly the regional ones, in fostering economic growth. Porter $[41,42]$ has argued that economic development is pursued by favoring not isolated companies but industrial clusters, which include firms, suppliers and also local institutions and research centers. Additional contributions have extended the notion of institutional quality to social capital endowment $[43,44,45]$ and institutional thickness [46]. Empirical evidence has pointed out that social cohesion [47] as well as the spread of collaborative 
and associative practices $[43,48,49]$ are drivers of economic development.

Notwithstanding the institutional quality has been investigated from decades to come, the role of institutional context on value creation in agricultural sector has gained attention only in the last few years $[16,50,13$, $51,14]$. Through disparate analytical perspectives, several theoretical and empirical studies have shown different relations between institutional quality and economic performance in agricultural sector $([6,14,51]$. Lin et al. [16], by using structural gravity models to measure how institutions affect the trade performance of some coconut producing countries, have shown that government effectiveness increases trade flows of high value coconut products. Conversely, Nadarajah and Flaaten, [13] by investigating the relationship between annual growth in aquaculture production and the quality of institutions, emphasized the insignificant correlation between aquaculture growth and the quality of institutions in analyzed countries. The institutional context has been also analyzed as determinant of voluntary traceability standards in the Italian wine sector (50).

A previous study, from Marotta and Nazzaro [14], theoretically analyzed the role of institutional context in new business models for value creation in agriculture sector. More deeply, according to the "value portfolio" (VP) model, macroeconomic factors such as territorial assets, the quality of institutions and policies play a strategic role on value creation in agricultural sector.

In other words, the VP of a farm is composed by organizational schemes in which internal resources of a farm (i.e. entrepreneurship and human resources; physical and financial resources; technological resources and networking) are combined with the external ones, such as social capital, fixed social capital and institutional context $[52,53,14]$. Based on what has been discussed so far, it is crucial to investigate also empirically the effect of institutional quality on labor productivity in agricultural sector.

\section{MATERIALS AND METHOD}

\subsection{Data}

In order to achieve the specific aims of the study a cross-section dataset from the FADN have been used. The dataset records information about statistically representative farms and farmers aspects. The FADN is composed by an annual survey carried out by the member states of the European Union. It is the unique source of microeconomic data based on the same principles in all European countries that aims to provide representative data along three dimensions: the economic size, type of farming and the region. More deeply, the aim of the network is to collect accounting data from farms in order to know incomes and to conduct business analyses of agricultural holdings with the aim of evaluating, ex-ante and ex-post, the impacts of the Common Agricultural Policy (CAP). Our analysis includes data on overall 773 Italian farms specialized in viticulture producing grapevines for quality wine (with certification of origin PDO/PGI or variety indication as regulated by EU Reg. 1308/2013 and Reg. 607/2011) and located in 71 Italian provinces of all Italian regions (Appendix A). A summary statistics of the variables included in the model is given in section 3.2.

In order to know information about the quality of institutions in Italian provinces, we referred to the institutional quality index. Major attention should be devoted to the IQI description. This is achieved in the following subsection.

\subsubsection{The IQI index}

The aim of this subsection is to describe the IQI that is getting momentum in recent scientific studies $[7,54,55,10]$. It is a composite indicator that measures the quality of Italian institutions at province level through the analytic hierarchy process [56] for the period 2004-2012. The following five dimensions: "Voice and Accountability", "Government Effectiveness", "Regulatory Quality", "Rule of Law" and "Control and Corruption" are the main components of the IQI. The first one concerns the degree of freedom of press and association, the second one is related to the quality of public services as well as the definition and the implementation of policies by the local government. The third refers to the ability of government to promote and formulate effective regulatory interventions, while the fourth accounts for the perception of the law application in terms of contract fulfilment, property rights, police forces, activities of the magistracy as well as crime levels. Lastly, the fifth dimension takes into account the degree of corruption of public employees. The IQI index is prompted by the World Governance Indicator (WGI) proposed by Kraay et al. [57] in the context of the Knowledge for Change Programme promoted by the World Bank. However, it considers only five of the six dimensions of the WGI. Indeed, the so-called "Political stability and absence of violence and terrorism" dimension is omitted in the IQI since it is related to the frequency of terrorist attacks and to the presence of military in politics, that are not relevant in Italy [9]. Each dimension is composed, in turn, by the aggregation of elementary indexes (see Figure 1) evaluated by data from institutional sources, 


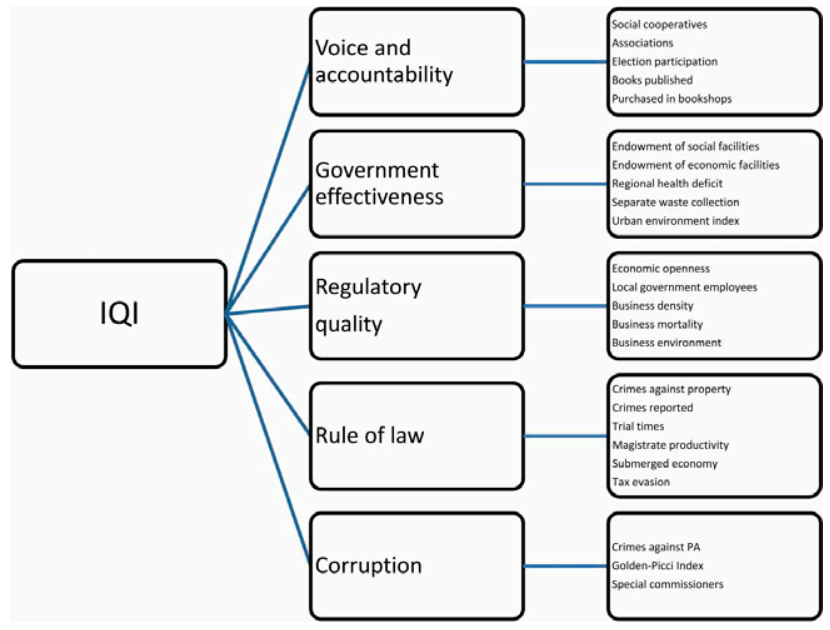

Figure 1. Dimensions and elementary indexes of IQI. Source: Structure of the Institutional Quality Index (IQI) from Lasagni et al, [7].

research institutes and professional registers. Appendix $B$ reports the list of all elementary indexes employed and sources.

As for the methodological approach, three steps have been implemented to obtain the IQI index from elementary indices, such as: normalization, attribution of weights to each index and aggregation. First of all, the elementary indices were normalized, then measured in the interval $[0,1]$, determining the distance of each of them from the maximum value found at the province level. Thus, through the analytical hierarchy process (AHP) [56], a weight was assigned to each normalized elementary index. Finally, once normalized and weighed, the elementary indices were aggregated to obtain the institution's quality index for 107 provinces - from 2004 to 2012 - which, by construction, takes values in the interval [0,1] [9]. Appendix B reports values of IQI of each Italian province and region included in the study.

\subsection{Method description}

The effect of institutional quality on labor productivity in Italian vineyard farms is assessed by designing the following Gaussian log-linear model:

$\ln \__{-} L P_{i}=\alpha+\beta$ young ${ }_{i}+\gamma$ farm $_{i}+\delta I Q I_{i}+\varepsilon_{i} \quad i=1,2 \ldots 773$.

where $l n_{-} L P$ is the logarithmic of the labor productivity for each $i$-farm. More specifically, the LP is the dependent variable of the model obtained by the ratio between the gross marketable output (GMO) and the work units employed in each farm (euro/worker).
Some control variables were chosen, including farmers and farms aspects, based on what the scientific literature considers as crucial elements for labor productivity in agricultural sector $[58,59,60,61,62,63,64,65,66]$. Young is a dummy variable, meaning the youth of the farmer that assumes value 1 if the farmer is 40 years old and 0 otherwise. In our model we called farm the vector of farms' variables. The vector includes five control variables, i.e. machines capital, land-labor ratio, circulating agricultural capital, irrigation and second pillar founding. The variable machines capital is the ratio between the economic value of machines and the used agricultural area (UAA), attached to the level of farm's investments in mechanization. The land-labor ratio variable, obtained by dividing the UAA per worker, giving information on the number of hectares per worker is a measure of the labor intensity. The circulating agricultural capital, defined as the ratio between the circulating agricultural capital and the (UAA), is an indicator that suggest the availability of euros per hectare. The irrigation variable is a dummy variable that assumes value 1 if the farm has irrigated land and 0 if the farm has not irrigated land. As for the second pillar founding variable, it is a dummy variable that means whether or not the farm received subsidies from the second pillar founding of the CAP. In other words, the variable assumes value 1 if the farm has received some payments for measures of Axis 2 from the Rural Development Plan and 0 otherwise.

The IQI is an explanatory variable of our model that measures, in the interval from 0 to 1 , the institutional quality of the province in which the farm is located. Finally, $\varepsilon$ is the error term.

A descriptive statistics of the variables included in the model is given in Table 1.

The average $L P$ is around 50 thousand euros. As for the age of farmers, only $13 \%$ is younger than 40 years. The average value of the machines capital is roughly 3 thousand euros per hectare, about 1 thousand euros lower than the average circulating agricultural capital per hectare (3985.73 euros/ha). As for the land-labor ratio, each worker has, on average, less than 10 hectares (9.22). The $38 \%$ is the percentage of the irrigated land, while the $47 \%$ is the percentage of farms that have received founding from the second pillar founding. Last, the average value of the IQI is 0.69 , with the lowest equal to 0.04 and the highest value equal to 1 (meaning the maximum of the IQI). 
Table 1. Descriptive statistics of the variables included in the statistical model.

\begin{tabular}{|c|c|c|c|c|c|}
\hline Variable name & Variable Description & Mean & Std. Dev. & Min & Max \\
\hline \multicolumn{6}{|l|}{ Dependent variable } \\
\hline LP & $\begin{array}{l}\text { Labor Productivity } \\
\text { (euro/worker). The ratio between the GMO and the units of labor }\end{array}$ & 48262.17 & 43514.6 & 1148.39 & 360860.8 \\
\hline \multicolumn{6}{|l|}{ Independent variables } \\
\hline Young & $\begin{array}{c}1=\text { under } 40 \text { years old; } \\
0=\text { otherwise }\end{array}$ & .13 & N.A. & 0 & 1 \\
\hline Machines capital & Ratio between machines capital and UAA (euro/ha) & 2949.81 & 7482.68 & 0 & 105383.8 \\
\hline Land-labor ratio & Available UAA per worker (ha/worker) & 9.22 & 9.54 & .64 & 107.25 \\
\hline Circulating Agricultural Capital & $\begin{array}{l}\text { Ratio between circulating agricultural capital and used agricultural } \\
\text { area (euro/ha) }\end{array}$ & 3985.73 & 17223.03 & 0 & 333915.2 \\
\hline Irrigation & $1=$ yes; $0=$ no & .38 & N.A. & 0 & 1 \\
\hline Second Pillar Founding & $1=$ yes; $0=$ no & .47 & N.A. & 0 & 1 \\
\hline IQI & Institutional Quality Index & 69 & .14 & .04 & 1 \\
\hline
\end{tabular}

N.A.: Not Applicable*.

Table 2. Effect of IQI (Institutional Quality Index) on value creation in vineyard farms. Gaussian log-linear model estimates.

\begin{tabular}{lccccc}
\hline Parameters & $\beta$ & Coef. $\left(e^{\beta)}\right.$ & Std. Err. & t & $p_{\text {-Value }}$ \\
\hline IQI & 0.330 & 1.39 & 0.17 & 1.88 & $0.060^{*}$ \\
Young & 0.104 & 1.11 & 0.07 & 1.43 & 0.155 \\
Machines_capital & 0.006 & 1.01 & 0.00 & 1.65 & $0.099^{*}$ \\
Circulating & 0.013 & 1.01 & 0.00 & 9.29 & $0.000^{* * *}$ \\
Agricultural Capital & 0.202 & 1.22 & 0.05 & 3.95 & $0.000^{* * *}$ \\
Irrigation & 0.115 & 1.12 & 0.05 & 2.33 & $0.020^{* *}$ \\
Second pillar founding & 0.035 & 1.03 & 0.00 & 13.44 & $0.000^{* * *}$ \\
Land-labor ratio & 9.719 & 16.63 & 0.13 & 72.80 & $0.000^{* * *}$ \\
Cons & & &
\end{tabular}

Note: $\mathrm{N}=773 ;{ }^{\star} \mathrm{p}$-value $<0.1 ;{ }^{* *} \mathrm{p}$-value $<0.05 ;{ }^{* *} \mathrm{p}$-value $<0.01 . \mathrm{R}^{2}=0.26$

\section{RESULTS}

\subsection{The Gaussian log-linear model estimates}

Results from the designed statistical model are summarized in Table 2. At a first glance, the coefficient of IQI has a significant and positive effect on LP, meaning that the institutional quality positively affects the labor productivity thus corroborating our research hypothesis. As for the impact of the institutional quality on the dependent variable, we followed Benoit [67] for interpreting coefficients with logarithmic transformation. In the log-linear model, the interpretation of estimated coefficient $\beta$ (see the second column of the Table 2) is that a one-unit increase in $\mathrm{X}$ will produce an expected increase in $\log \mathrm{Y}$ of $\beta$ units. In terms of $\mathrm{Y}$, this means that the expected value of $\mathrm{Y}$ is multiplied by $e^{\beta}$. Briefly, in terms of effects of changes in X on Y (unlogged), each 1-unit increases in $\mathrm{X}$ multiplies the expected value of $\mathrm{Y}$ by $e^{\beta}$. Accordingly, the impact of the IQI on LP is quantified in 39\% (the third column of the Table 2). This means that going from the lowest level of the IQI (equal to 0 ) to the maximum one (equal to 1), the labor productivity will increase by $39 \%$ in Italian vineyard farms. Except for young, all control variables are statistically significant. More deeply, all of them have a positive effect on LP.

\subsection{The sensitivity analysis of the IQI index}

The sensitivity analysis allows to determine and to quantify the impact of small input perturbations on the model output [68]. Thus, we have carried out several perturbations to the IQI index. More deeply, we have assigned several different values to the institutional 
Table 3. Assumptions tested in the sensitivity analysis.

\begin{tabular}{lc}
\hline Assumptions & $\begin{array}{c}\text { Average labor productivity } \\
\text { (euro/worker) }\end{array}$ \\
\hline The IQI index is equal to $\mathbf{0}$ & 42901.02 \\
The IQI index is equal to $\mathbf{0 . 1}$ & 44340.35 \\
The IQI index is equal to $\mathbf{0 . 2}$ & 45827.97 \\
The IQI index is equal to $\mathbf{0 . 3}$ & 47365.49 \\
The IQI index is equal to $\mathbf{0 . 4}$ & 48954.60 \\
The IQI index is equal to $\mathbf{0 . 5}$ & 50597.03 \\
The IQI index is equal to $\mathbf{0 . 6}$ & 52294.56 \\
The IQI index is equal to $\mathbf{0 . 7}$ & 54049.04 \\
The IQI index is equal to $\mathbf{0 . 8}$ & 55862.39 \\
The IQI index is equal to $\mathbf{0 . 9}$ & 57736.57 \\
The IQI index is equal to $\mathbf{1}$ & 59673.63 \\
\hline
\end{tabular}

quality index in the range from 0 to $1(0,0.1,0.2,0.3$, $0.4,0.5,0.6,0.7,0.8,0.9$ and 1$)$ where 0 corresponds to the minimum level of the institution quality while 1 is the maximum value. Afterwards, we have quantified the average labor productivity, at each level of IQI (Table 3).

In the Figure 2 we have plotted the LP (y-axis) versus the perturbations of the IQI(x-axis). The graph reveals the linear effect of institutional quality index on the LP. Specifically, the sensitivity analysis indicated that the institutional context has a positive and constant impact on labor productivity in vineyard farms. The slope of the line in Figure 2 is the sensitivity of the LP with respect to the IQI (by taking fixed the other variables).In particular, as shown by the statistical model, if the IQI index is equal to 1 the average LP is $39 \%$ higher than that obtained under the IQI index equal to 0 .

In Table 4, the difference between the average LP at region level by considering the current IQI and that obtained by giving to all provinces the maximum IQI value (i.e. equal to 1 ) suggests the economic loss, in terms of labor productivity, due to low institutional quality. The developed analysis shows that the LP in the

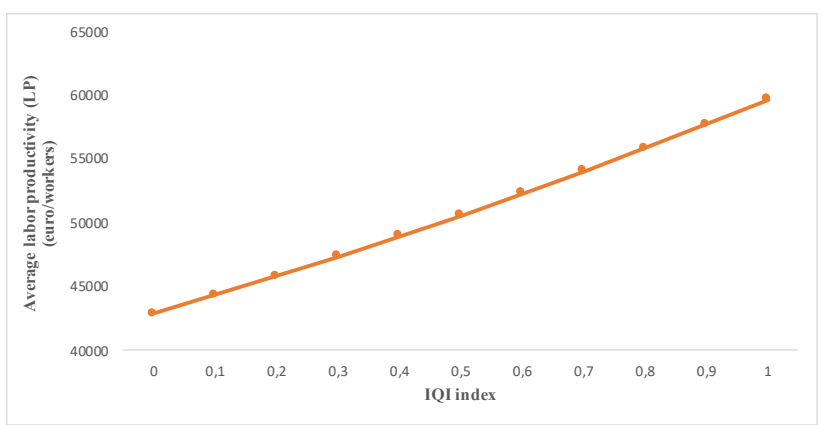

Figure 2. The sensitivity analysis changing IQI index.
Table 4. The average labor productivity (LP) in Italian regions at current IQI and at maximum value of IQI (equal to 1) in all Italian provinces.

\begin{tabular}{|c|c|c|c|}
\hline & $\begin{array}{l}\text { Average LP } \\
(\text { tEur/w) at } \\
\text { current IQI }\end{array}$ & $\begin{array}{c}\text { Average LP } \\
\text { (tEur/w) at } \\
\text { IQI equal to } \\
1 \text { in Italian } \\
\text { provinces }\end{array}$ & $\begin{array}{c}\text { Economic loss } \\
\text { (\%) due to low } \\
\text { institutional } \\
\text { quality }\end{array}$ \\
\hline Trentino Alto Adige & 139633 & 146329 & 4.80 \\
\hline Tuscany & 44225 & 47043 & 6.37 \\
\hline Abruzzo & 37970 & 40589 & 6.90 \\
\hline Emilia Romagna & 110657 & 119892 & 8.35 \\
\hline Valle D’Aosta & 57200 & 62182 & 8.71 \\
\hline Veneto & 46239 & 50291 & 8.76 \\
\hline Umbria & 72550 & 79120 & 9.05 \\
\hline Friuli Venezia Giulia & 49611 & 54512 & 9.88 \\
\hline Piedmont & 46027 & 50775 & 10.32 \\
\hline Lombardy & 45512 & 50218 & 10.34 \\
\hline Marche & 43628 & 48158 & 10.38 \\
\hline Lazio & 46242 & 52960 & 14.53 \\
\hline Liguria & 45628 & 53438 & 17.12 \\
\hline Campania & 35125 & 41444 & 17.99 \\
\hline Puglia & 44793 & 54109 & 20.80 \\
\hline Sardinia & 76916 & 93006 & 20.92 \\
\hline Basilicata & 45715 & 55770 & 21.99 \\
\hline Molise & 48154 & 62701 & 30.21 \\
\hline Sicily & 60323 & 78563 & 30.24 \\
\hline Calabria & 31245 & 42894 & 37.28 \\
\hline
\end{tabular}

Italian regions and macro-areas (Northern, Southern and Central) is not homogeneous.

More specifically, it is possible to state that in Calabria the average economic loss caused by the low quality of institutions is more than $37 \%$. Conversely, in Trentino Alto Adige the average economic loss is roughly $5 \%$. Moreover, the economic loss increases by passing from the North to the Southern regions, as shown in the last column of the Table 4. Accordingly, investments for improving the institutional quality in the Southern regions would enhance the labor productivity in vineyard farms, thus improving the agricultural sector in underdeveloped areas.

\section{DISCUSSIONS}

The present paper had three specific goals. First, it developed, for the first time, an empirical study to analyze the relation between the institutional quality of the Italian provinces and labor productivity in Italian vineyard farms. Second, once answered to the first aim, the 
study quantified the effect size of the institutional quality on the economic value created per worker and finally, it measured the impact of the institutional quality on labor productivity in vineyard farms located in all Italian regions and macro-areas (North, South and Central Italy). To this end, we developed a Gaussian log-linear model, which considers the ratio between the gross marketable output and the number of workers employed in each farm as the dependent variable of the statistical model. Further, the IQI is one of the independent variables together with the farms and farmers' aspects. The model output highlighted a significant and positive effect of the institutional quality on labor productivity in Italian vineyard farms.

Although there are no previous empirical studies about the effect of institutional quality of Italian provinces on labor productivity in agricultural sector, our findings are consistent with previous theoretical and empirical studies developed in non-agricultural sector $[5,14,51,69,9,7,70]$. Based on the study findings, one can state that vineyard farms operating in a good institutional context consistently increase the labor productivity. Several reasons may explain this result. First, getting the "right" price from the market and reducing the transaction costs is helpful in increasing the gross marketable output. Several authors, from decades to come, have indeed highlighted the role of both formal and informal institutions in improving the level and quality of entrepreneurship [71] as well as in removing the market imperfections and the transaction costs $[1$, 32]. Furthermore, a favorable institutional context (in terms of bureaucracy efficiency and economic facilities) encourages farms to invest in technology and mechanization $[18,7]$, thus increasing the economic value created through the intensification of output produced per worker. The availability of economic facilities is also helpful for improving crop productivity and technical efficiency by the increase of financial services [72]. Further, associations and social cooperatives are helpful tools for labor productivity by overcoming market imperfections and constraints [73, 74, 75, 76]. Indeed, according to Fischer and Qaim [77] social cooperatives increase farm income and profit. Moreover, being part of social cooperatives and associations may improve labor productivity by sharing knowledge and information among workers.

As for the measure of the effect of the institutional quality on the average labor productivity in vineyard farms located in the North, South and in the Central Italy, the finding showed the lowest LP in farms located in the Southern regions. This is in agreement with the work of Lasagni and co-authors [7]) who showed that the total factor productivity in manufacturing firms is lower in industries located in the Southern Italian regions than those located in the Northern and in the Central ones. Differences in LP among Italian vineyard farms may be attributed to differences in transport and infrastructures [78] as well as to institutional factors [79]. More deeply, as for the transport field, according to Carlucci et al. [78] the Southern Italy suffers from an infrastructure and logistic gap compared to Northern Italian regions and, in the same regions, bureaucracy is less efficient in terms of costs and time required [80]. Moreover, widespread differences among Italian macroareas are also shown in terms of corruption. Indeed, 6 of the 7 Southern regions have the number of reported crimes higher than the national average, meaning a high index of corruption that is a relevant issue in transport infrastructure financing and service provision $[81,82$, 78]. To summarize, the main result of this study not only confirms the well known differences in endowments of institutional quality among Italian provinces, but it pointed out, for the first time, that these differences also affect economic performances, specifically the LP in the Italian vineyard farms.

The impacts of control variables assessed in this research, except for the "young" one, are also significant and they are in line with scientific evidences. First, the higher capital endowment, both in terms of machines and financial capital, increases the LP. These results are consistent with previous studies in which the mechanization at farm level is a very critical tool for enhancing economic productivity $[58,66]$. Mechanization improves value created per workers in two ways: i) reducing the hard labor (and, consequently, drudgery) and ii) improving gross marketable output through the timeless of agricultural operations $[59,63]$. Conversely, the un-mechanized agriculture reveals much more negative economic performances $[60,64]$. On the other hand, the availability of financial capital is helpful in purchase inputs of production, such as fertilizers and pesticides. Indeed, a good amount of economic capital allows a huge consistency of fertilizers and pesticides increasing crop yield and, once again, the gross marketable output per workers [62]. Likewise, the endowment of irrigated hectares may enhance value created reducing the risk of yield loss in vineyard farms located in the Mediterranean area, where a deficit of irrigation reduces the yield of grape [61]. As for the second pillar founding, the model output has shown a positive impact on LP. It is a natural result since several measures of the second pillar of the CAP providing physical investments ${ }^{1}$ could enhance the

${ }^{1} \mathrm{http}: / /$ www.europarl.europa.eu/factsheets/en/sheet/110/second-pillarof-the-cap-rural-development-policy 
output per workers. A positive role on value creation is also played by the land-labor ratio variable, in agreement with Urgessa [62] and Fuglie [65]. The latter highlighted that the growth of population in rural areas-through the decline of the ratio between land and labor - can reduce the average output per workers [65].

\section{CONCLUSIONS AND POLICY IMPLICATIONS}

The present study analyses, for the first time, the effect of macroeconomic aspects, e.g. the quality of institution, on labor productivity in Italian farms. To this end, we built a cross-section dataset of overall 773 Italian farms specialized in viticulture and located in 71 Italian provinces, where both micro and macroeconomic aspects are considered. Then, data were analyzed by means of a Gaussian log-linear model in order to grasp the effect of the institutional quality on LP. Despite some limitations, among the others the specificity of the farms (vineyard farms) considered for the research and the type of the dataset used (cross-section), results assign a critical role to the business environment and institutional quality into determining labor productivity differentials in Italian vineyard farms, in accordance with previous conceptualizations and empirical studies. This means that the economic performance of vineyard farms does not depend on internal resources of farms solely, but it is also affected by the quality of institutions in which farms operate. However, the variables (which we have shown to have a significant and positive impact on LP) that were used in the present study to describe the institutional quality, are not managed by farmers neither by the CAP instruments. As a consequence, the findings of the present study have theoretical and political implications. As for the former, a wide discussion can be found in pervious publications where the role of institutional context on economic performances of farms is discussed $[83,84,69,51]$. As for the political implications, it should be emphasized that critical aspects for the agricultural development, such as infrastructure facilities, bureaucracy efficiency and business environment, are not influenced by the CAP. However, in the last decades, the policy makers have considered the second pillar of the CAP the only available tool to enhance the rural development, without considering the general EU development strategies. These latter, meaning the European Regional Development Found (ERDF) and the European Social Found (ESF), were indeed never integrated within the European Agricultural Fund for Rural Development (EAFRD), since they are almost exclusively implemented in urban areas.
Given the findings of the present study, one can state that the integration among different EU strategies is crucial to develop the agricultural sector, especially in Italian underdeveloped (typically southern) regions. As a consequence, since the institutional quality plays an important role in increasing the economic performances of farms, balancing all the EU strategies should be the main aim of the policy maker for the next programming period (2021-2027). An effective integration among EU strategies is needed to improve the agricultural sector to which citizens require many challenges, such as a better quality of food and environment as well as social sustainability.

\section{REFERENCES}

[1] North, D. C.,. Institutions. J. Econ. Perspect., 5(1), 97-112 (1991). DOI: 10.1257/jep.5.1.97

[2] OECD, Territorial Outlook 2001, Organization for Economic Cooperation and Development: Paris (2001).

[3] Commander, S., \& Svejnar, J., Business environment, exports, ownership, and firm performance. Rev. Econ. Stat., 93(1), 309-337 (2011). DOI: https://doi. org/10.1162/REST_a_00135

[4] Bhaumik, S. K., Dimova, R., Kumbhakar, S. C., \& Sun, $\mathrm{K}$., Is tinkering with institutional quality a panacea for firm performance? Insights from a semiparametric approach to modeling firm performance. Rev. Dev. Econ., 22(1), 1-22 (2018). DOI:https://doi.org/10.1111/ rode. 12311

[5] Hall, R. E., \& Jones, C. I., Why do some countries produce so much more output per workers than others?. Q. J. Econ., 114(1), 83-116 (1999). DOI: 10.3386/w6564

[6] Easterly, W., \& Levine, R., Tropics, germs, and crops: how endowments influence economic development. J. Monet. Econ., 50(1), 3-39 (2003). DOI: https://doi. org/10.1016/S0304-3932(02)00200-3

[7] Lasagni, A., Nifo, A., \& Vecchione, G., Firm productivity and institutional quality: Evidence from Italian industry. J. Reg. Sci., 55(5), 774-800 (2015). DOI: https://doi.org/10.1111/jors.12203

[8] Rodríguez-Pose, A., \& Storper, M., Better rules or stronger communities? On the social foundations of institutional change and its economic effects Econ. Geogr., 82(1), 1-25 (2006). DOI: 10.1111/j.19448287.2006.tb00286.x

[9] Nifo, A., \& Vecchione, G., Do institutions play a role in skilled migration? The case of Italy. Reg. Stud., 48(10), 1628-1649 (2014). DOI: $10.1080 / 00343404.2013 .835799$ 
[10]Ferrara, A. R., \& Nisticò, R., Does Institutional Quality Matter for Multidimensional Well-Being Inequalities? Insights from Italy. Soc. Indic. Res., 1-43 (2019). DOI: https://doi.org/10.1007/s11205-019-02123-x

[11]Rodrik, D., Subramanian, A., \& Trebbi, F., Institutions rule: the primacy of institutions over geography and integration in economic development. $\mathrm{J}$. Econ. Growth, 9(2), 131-165 (2004). DOI: https://doi. org/10.1023/B:JOEG.0000031425.72248.85

[12] Herger, N., Kotsogiannis, C., \& McCorriston, S. Cross-border acquisitions in the global food sector. Eur. Rev. Agric. Econ., 35(4), 563-587 (2008). DOI: 10.1093/erae/jbn033

[13]Nadarajah, S., \& Flaaten, O., Global aquaculture growth and institutional quality. Mar. Policy, 84, 142151 (2017).DOI:10.1016/j.marpol.2017.07.018

[14] Marotta G., Nazzaro C., Verso un nuovo paradigma per la creazione di valore nell'impresa agricola multifunzionale. Il caso della filiera zootecnica. Economia Agro-Alimentare, 1-2, 215-250, Milano, FrancoAngeli (2011). DOI: https://doi.org/10.3280/ecag2011001011

[15] Pascucci, S., Gardebroek, C., \& Dries, L. Some like to join, others to deliver: an econometric analysis of farmers' relationships with agricultural co-operatives. Eur. Rev. Agric. Econ., 39(1), 51-74 (2011). DOI: 10.1093/erae/jbr027

[16]Lin, J., I. Flachsbarth, S. von Cramon-Taubadel,The role of institutional quality on the performance in the export of coconut products. Global Food Discussion Paper 126, University of Goettingen. http://www.unigoettingen.de/de/213486.html (2018).

[17]Zhou, Y. Role of institutional quality in determining the R\&D investment of Chinese firms. China \& World Economy, 22(4), 60-82 (2014). DOI: https:// doi.org/10.1111/j.1749-124X.2014.12075.x

[18]Loayza, N. V., Oviedo, A. M., \& Servén, L., The Impact Of Regulation On Growth And InformalityCross-Country Evidence, Vol. 1 Of 1. The World Bank (2005). DOI:10.1093/0199204764.003.0007

[19] Bowen H. P. \& De Clerco D., Institutional context and the allocation of entrepreneurial effort, J. Int. Bus. Stud. 39, 747-67 (2008). DOI:10.1057/palgrave. jibs. 8400343

[20] Anderson, K., \& Nelgen, S., Global wine markets, 1961 to 2009: a statistical compendium. University of Adelaide Press (2011). DOI: https://doi.org/10.20851/ global-wine-markets

[21] Sellers, R., \& Alampi-Sottini, V., The influence of size on winery performance: Evidence from Italy. Wine Economics and Policy, 5(1), 33-41 (2016). DOI: http://dx.doi.org/10.1016/j.wep.2016.03.001
[22]Urso, A., Timpanaro, G., Caracciolo, F., \& Cembalo, L., Efficiency analysis of Italian wine producers. Wine Economics and Policy, 7(1), 3-12 (2018). DOI:10.1016/j.wep.2017.11.003

[23]Aurand, J., OIV Statistical Report on World Vitiviniculture. International Organization of Vine and Wine: Paris, France (2017).

[24]De Salvo, M., Capitello, R., Gaudenzi, B., \& Begalli, D., Risk management strategies and residual risk perception in the wine industry: A spatial analysis in Northeast Italy. Land use policy, 83, 47-62 (2019). DOI: https://doi.org/10.1016/j.landusepol.2019.01.022

[25]Di Vita, G., Caracciolo, F., Cembalo, L., Pomarici, E., \& D'Amico, M., Drinking wine at home: Hedonic analysis of Sicilian wines using quantile regression. Am. J. Appl. Sci, 12 (10),679-688 (2015). DOI :10.3844/ajassp.2015.679.688

[26] Barro R. \& Lee J., Losers and winners in economic growth. NBER Working Paper No. 4341(1993). DOI: $10.3386 / \mathrm{w} 4341$

[27] Nugent J.B., Between State, market and households: A neo-institutional analysis of local organizations and institutions, World Dev. 21, 623-632 (1993). DOI: https://doi.org/10.1016/0305-750X(93)90114-O

[28] Mauro P., Corruption and growth. Q. J. Econ. 110, 681-712 (1955). DOI:https://doi.org/10.2307/2946696

[29] World Development Report The State in a Changing World. Oxford University Press (1997). DOI: 10.1596/978-0-1952-1114-6

[30]Brunetti A., Political variables in cross-country growth analysis, J. Econ. Surv. 11, 163-190 (1997). DOI:10.1111/1467-6419.00029

[31] Knack S. \& Keefer P., Does social capital have an economic payoff? A cross-country investigation, Q. J. Econ. 112, 1251-1288 (1997). DOI:http://dx.doi. org/10.1162/003355300555475

[32]Djankov, S., La Porta, R., Lopez-de-Silanes, F., \& Shleifer, A., The regulation of entry. Q. J. Econ., 117(1), 1-37 (2002). DOI:10.3386/w7892

[33]Schermer, M., Darnhofer, I., Daugstad, K., Gabillet, M., Lavorel, S., \& Steinbacher, M., Institutional impacts on the resilience of mountain grasslands: an analysis based on three European case studies. Land Use Policy, 52, 382-391 (2016). DOI: https://doi. org/10.1016/j.landusepol.2015.12.009

[34]Helliwell J. F. \& Putnam R., Economic growth and social capital in Italy, East. Econ. J. 21, 3 (1995).

[35]Barro R. \& Sala-I-Martin X., Economic Growth, McGraw Hill (1995).

[36] Arrighetti A. \& Serravalli G. (Eds.), Istituzioni intermedie e sviluppo locale, Donzelli, Rome (1999). DOI: https://doi.org/10.1017/S146722270000094X 
[37]Dall'Aglio V., Istituzioni intermedie e dinamica della distribuzione del reddito nelle province italiane: una verifica empirica non parametrica, in A. Arrighetti and G. Seravalli (Eds.), Donzelli editore, Rome (1999).

[38] McGuinness, A. "Institutions and Total Factor Productivity Convergence," Working Paper No.9, Central Bank and Financial Services Authority of Ireland (2007).

[39]Chanda A. \& Dalgaard C.J.,Dual economies and International total factor productivity differences: channelling the impact from institutions, trade and geography, Economica 75, 629-661 (2008). DOI:https://doi.org/10.1111/j.1468-0335.2007.00673.x

[40]Acemoglu, D., \& Robinson, J., The role of institutions in growth and development. Leadership and growth, 135 (2010). DOI:10.5202/rei.v1i2.14

[41] Porter M.E., New strategies for inner city economic development, Econ. Dev. Q. 11, 11-27 (1997). DOI: https://doi.org/10.1177/089124249701100102

[42] Porter M.E., The economic performance of regions, Reg. Stud. 37, 549-578 (2003).DOI: https://doi.org/10.1080/0034340032000108688

[43] Putnam R.D.,. Making Democracy Work: Civic Traditions in Modern Italy, Princeton University Press (1993a). DOI: https://doi.org/10.1016/S0030-4387(96)90074-5

[44] Narayan D. \& Pritchett L.,. Cents and sociability: Household income and social capital in rural Tanzania. Econ Dev Cult Change, 47, 871-97 (1997). DOI:http://dx.doi.org/10.1086/452436

[45] Woolcock M., Social capital and economic development: toward a theoretical synthesis and policy framework, Theory Soc., 27, 151-208 (1998). DOI:10.1023/A:1006884930135

[46]Amin, A., \& Thrift, N., Globalisation, institutional 'thickness' and the local economy. Managing cities: The new urban context, 12, 91-108 (1995).

[47]Ritzen, J., Easterly W. \& Woolcock M., 2000. On 'Good' politicians and 'Bad' policies: Social cohesion, institutions and growth. World Bank Working Paper No. 2448. DOI:10.1596/1813-9450-2448

[48] Putnam R.D.,. The prosperous community. Social capital and public life. American Prospect 13, 35-42 (1993b).

[49] Narayan D., Social capital and the State: Complementarity and substitution, World Bank Working Paper No. 2167 (1999). DOI: 10.1596/1813-9450-2167

[50]Stranieri, S., Cavaliere, A., \& Banterle, A., The determinants of voluntary traceability standards. The case of the wine sector. Wine economics and Policy, 7(1), 45-53 (2018). DOI: https://doi.org/10.1016/j. wep.2018.02.001
[51] Marotta G., Nazzaro C., Simeone M., Capitale umano e capitale sociale nellagricoltura multifunzionale: un'analisi delle esperienze di filiera corta nella Campania interna. Economia Agro-Alimentare, 15 (3), 149-173, Milano, FrancoAngeli (2013). DOI:10.3280/ ECAG2013-003009

[52] Marotta, G., \& Nazzaro, C., Public goods production and value creation in wineries: a structural equation modelling. British Food Journal. (2020). https://doi. org/10.1108/BFJ-08-2019-0656

[53]Nazzaro, C., Stanco, M., \& Marotta, G., The Life Cycle of Corporate Social Responsibility in AgriFood: Value Creation Models. Sustainability, 12(4), 1287 (2020). https://doi.org/10.3390/su12041287

[54] Agovino, M., Ferrara, M., \& Garofalo, A., An exploratory analysis on waste management in Italy: A focus on waste disposed in landfill. Land Use Policy, 57, 669-681 (2016). DOI: https://doi.org/10.1016/j.landusepol.2016.06.027

[55] Arbolino, R., \& Boffardi, R., The impact of institutional quality and efficient cohesion investments on economic growth evidence from Italian regions. Sustainability, 9(8), 1432 (2017). doi:10.3390/su9081432

[56] Saaty, T. L., The Analytic Hierarchy Process:, New York, NY, McGraw Hill, reprinted by RWS Publication, Pittsburgh (1980).

[57]Kraay, A., Kaufmann, D., \& Mastruzzi, M., The worldwide governance indicators: methodology and analytical issues. The World Bank (2010).

[58] Okoye, B. C., Onyenweaku, C. E., Ukoha, O. O., Asumugha, G. N., \& Aniedu, O. C.,. Determinants of labour productivity on small-holder cocoyam farms in Anambra State, Nigeria. Sci. Res. Essays, 3(11), 559-561(2008).

[59] Krozer, Y., Life cycle costing for innovations in product chains. J. Clean. Prod., 16(3), 310-321 (2008). DOI:10.1016/j.jclepro.2006.07.040

[60] Eastwood, R., M. Lipton, and A. Newell.,"Farm Size." In Handbook of Agricultural Economics, edited by P.L. Pingali and R. E. Evenson. Amsterdam: Elsevier (2010). DOI: https://doi.org/10.1016/S1574-0072(09)04065-1

[61]Lopes, C. M., Santos, T. P., Monteiro, A., Rodrigues, M. L., Costa, J. M., \& Chaves, M. M., Combining cover cropping with deficit irrigation in a Mediterranean low vigor vineyard. Sci Hortic, 129(4), 603-612 (2011).DOI:10.1016/j.scienta.2011.04.033

[62] Urgessa, T., The determinants of agricultural productivity and rural household income in Ethiopia. Ethiopian Journal of Economics, 24(2), 63-91 (2015). DOI:10.22004/ag.econ.259494

[63] Sims, B., \& Kienzle, J., Sustainable agricultural mechanization for smallholders: What is it and how 
can we implement it?. Agriculture, 7(6), 50 (2017). DOI:https://doi.org/10.3390/agriculture7060050

[64] Deininger, K., Jin, S., Liu, Y., \& Singh, S. K., Can Labor-Market Imperfections Explain Changes in the Inverse Farm Size-Productivity Relationship? Longitudinal Evidence from Rural India. Land Econ., 94(2), 239-258 (2018). DOI:10.3368/le.94.2.239

[65]Fuglie, K. O., Is agricultural productivity slowing? Glob food secur, 17, 73-83 (2018). DOI:10.1016/j. gfs.2018.05.001

[66] Kirui, O., \& von Braun, J., Mechanization in African Agriculture: A Continental Overview on Patterns and Dynamics. Working Paper 169, Center for Development Research (2018). DOI:http://dx.doi. org/10.2139/ssrn.3194466

[67]Benoit, K.,Linear regression models with logarithmic transformations. London School of Economics, London, 22(1), 23-36 (2011).

[68] Iooss, B., \& Lemaître, P., A review on global sensitivity analysis methods. In Uncertainty management in simulation-optimization of complex systems (pp. 101-122). Springer, Boston, MA (2015). DOI:10.1007/978-1-4899-7547-8_5

[69] Marotta G., Nazzaro C., Stanco M.,. "How the social responsibility creates value: models of innovation in italian pasta industry”. Int. Small Bus. J., 9(2-3), 144167 (2017). DOI:10.1504/IJGSB.2017.088923

[70]Kaasa, A., Social capital, institutional quality and productivity: evidence from European regions. Econ. Sociol., 9(4), 11 (2016). DOI: 10.14254/2071789X.2016/9-4/1

[71]Urbano, D., Aparicio, S., \& Audretsch, D., Twentyfive years of research on institutions, entrepreneurship, and economic growth: what has been learned? Small Bus. Econ., 53(1), 21-49 (2019). DOI: https:// doi.org/10.1007/s11187-018-0038-0

[72]Elahi, E., Abid, M., Zhang, L., ul Haq, S., \& Sahito, J. G. M., Agricultural advisory and financial services; farm level access, outreach and impact in a mixed cropping district of Punjab, Pakistan. Land use policy, 71, 249-260 (2018). DOI: https://doi. org/10.1016/j.landusepol.2017.12.006

[73] Verhofstadt, E., \& Maertens, M., Can agricultural cooperatives reduce poverty? Heterogeneous impact of cooperative membership on farmers' welfare in Rwanda. Appl. Econ. Perspect. Policy, 37(1), 86-106 (2014). DOI:10.1093/aepp/ppu021

[74] Shumeta, Z., \& D'Haese, M.,. Do coffee cooperatives benefit farmers? An exploration of heterogeneous impact of coffee cooperative membership in Southwest Ethiopia. Int. Food Agribus. Man., 19(4), 37-52 (2016). DOI:10.22434/IFAMR2015.0110
[75]Raimondo, M., Caracciolo, F., Cembalo, L., Chinnici, G., Pecorino, B., \& D’Amico, M.,. Making Virtue Out of Necessity: Managing the Citrus Waste Supply Chain for Bioeconomy Applications. Sustainability, 10(12), 4821 (2018). DOI:10.20944/preprints201810.0511.v1

[76]De Rosa, M., McElwee, G., \& Smith, R. Farm diversification strategies in response to rural policy: a case from rural Italy. Land use policy, 81, 291-301 (2019). DOI: https://doi.org/10.1016/j.landusepol.2018.11.006

[77].Fischer, E., \& Qaim, M., Linking smallholders to markets: determinants and impacts of farmer collective action in Kenya. World Dev., 40(6), 12551268 (2012). DOI: https://doi.org/10.1016/j.worlddev.2011.11.018

[78] Carlucci, F., Cirà, A., Immordino, G., Ioppolo, G., \& Yigitcanlar, T., Regional heterogeneity in Italy: Transport, devolution and corruption. Land use policy, 66, 28-33 (2017). DOI: https://doi.org/10.1016/j.landusepol.2017.04.020

[79] Musolino, D., The North-South Divide in Italy: Reality or Perception? European Spatial Research and Policy, 25(1), 29-53 (2018). DOI: https://doi. org/10.18778/1231-1952.25.1.03

[80] World Bank; International Finance Corporation. Doing Business in Italy 2013: Smarter Regulations for Small and Medium-Size Enterprises. Doing Business Subnational. Washington, DC. (c) World Bank. https://openknowledge.worldbank.org/handle/10986/13332 License: CC BY-NC-ND 3.0 IGO (2013).

[81] Asmundo, A., \& Lisciandra, M., The cost of protection racket in Sicily. Glob. Crime, 9(3), 221-240 (2008). DOI:10.1080/17440570802254338

[82]Bonaccorsi di Patti, E., 2009. Weak institutions and credit availability: the impact of crime on bank loans. Bank of Italy Occasional Paper, (52). DOI:http://dx.doi.org/10.2139/ssrn.1606242

[83] Nazzaro C. and Marotta G., The Common Agricultural Policy 2014-2020: scenarios for the European agricultural and rural systems. Agric \& food econ, 4(1),16 (2016). DOI:10.1186/s40100-016-0060-y

[84] Marotta G., Nazzaro C., Value portfolio in the multifunctional farm: new theoretical-methodological approaches. Rivista di economia Agraria, n. 2, pp. 7-36 (2012). DOI: 10.3280/REA2012-002001 
APPENDIX A

Table 1A. Number of vineyard farms located in each considered province.

\begin{tabular}{|c|c|c|c|c|c|c|c|}
\hline Province & Number of farms & Province & Number of farms & Province & Number of farms & Province & Number of farms \\
\hline Agrigento & 3 & Firenze & 22 & Palermo & 1 & Salerno & 1 \\
\hline Alessandria & 55 & Foggia & 1 & Pavia & 4 & Sassari & 4 \\
\hline Ancona & 17 & Forlì-Cesena & 1 & Perugia & 26 & Siena & 3 \\
\hline Aosta & 51 & Genova & 3 & Pesaro e Urbino & 4 & Sondrio & 6 \\
\hline Arezzo & 5 & Gorizia & 20 & Pescara & 10 & Taranto & 7 \\
\hline Ascoli Piceno & 20 & Grosseto & 15 & Piacenza & 1 & Teramo & 9 \\
\hline Asti & 57 & Imperia & 4 & Pisa & 1 & Terni & 17 \\
\hline Avellino & 1 & Isernia & 9 & Pistoia & 1 & Torino & 1 \\
\hline Benevento & 15 & La Spezia & 6 & Pordenone & 42 & Trapani & 3 \\
\hline Bergamo & 5 & Latina & 1 & Potenza & 2 & Trento & 21 \\
\hline Bologna & 3 & Lecce & 3 & Prato & 1 & Treviso & 15 \\
\hline Bolzano/Bozen & 18 & Lucca & 1 & Ragusa & 2 & Trieste & 1 \\
\hline Brescia & 12 & Macerata & 1 & Ravenna & 5 & Udine & 41 \\
\hline Brindisi & 38 & Mantova & 7 & $\begin{array}{l}\text { Reggio di } \\
\text { Calabria }\end{array}$ & 2 & Venezia & 9 \\
\hline Cagliari & 8 & Modena & 4 & $\begin{array}{c}\text { Reggio } \\
\text { nell'Emilia }\end{array}$ & 3 & Verona & 19 \\
\hline Caserta & 3 & Novara & 1 & Rieti & 1 & Vicenza & 7 \\
\hline Chieti & 36 & Nuoro & 1 & Rimini & 1 & Viterbo & 5 \\
\hline Cuneo & 41 & Padova & 6 & Roma & 3 & & \\
\hline
\end{tabular}

Source: FADN dataset.

\section{APPENDIX B}

Table 2A. Structure of elementary IQI indexes

\begin{tabular}{|c|c|c|c|}
\hline Index & Value & Source (details in notes) & Year \\
\hline \multicolumn{4}{|l|}{ Voice and accountability } \\
\hline Social cooperatives & Absolute Value $^{1}$ & ISTAT & 2001 \\
\hline Associations & Absolute Value $^{1}$ & ISTAT & 2004 \\
\hline Election participation & Turnout $\%^{2}$ & Interior Ministry & 2001 \\
\hline Books published & Absolute Value ${ }^{3}$ & ISTAT & 2007 \\
\hline Purchased in bookshops & Index ${ }^{4}$ & Sole24Ore & 2004 \\
\hline \multicolumn{4}{|l|}{ Government effectiveness } \\
\hline Endowment of social facilities & Index 5 & Tagliacarne & 2001 \\
\hline Endowment of econ. facilities & Index ${ }^{6}$ & Tagliacarne & 2001 \\
\hline Regional health deficit & Absolute Value $^{7}$ & $\mathrm{MEF}$ and $\mathrm{MH}$ & $1997-2004$ \\
\hline Separate waste collection & Separate/total ${ }^{8}$ & Tagliacarne & 2007 \\
\hline Urban environment index & Index 9 & Legambiente & 2004 \\
\hline \multicolumn{4}{|l|}{ Regulatory quality } \\
\hline Economy openness & Index ${ }^{10}$ & Tagliacarne & 2001 \\
\hline Local government employees & Absolute Value ${ }^{11}$ & ISTAT & 2003 \\
\hline Business density & Index ${ }^{12}$ & Tagliacarne & 2008 \\
\hline Business start-ups/mortality & Registration/cessation $^{13}$ & Tagliacarne & 2003-2004 \\
\hline Business environment & Index $^{14}$ & Confartigianato & 2009 \\
\hline
\end{tabular}




\begin{tabular}{lccc}
\hline Rule of law & & & \\
Crimes against property & Absolute Value & \\
Crimes reported & Absolute Value & & 2003 \\
Trial times & Trial lengths I, II, III & & 2003 \\
Magistrate productivity & MagistrateTrials $^{18}$ & ISTAT & 1999 \\
Submerged economy & Index $^{19}$ & ISTAT & $2004-2008$ \\
Tax evasion & Index $^{20}$ & Ministry of Justice & 2003 \\
Corruption & & ISTAT & $1998-2002$ \\
Crimes against PA & Index $^{21}$ & Revenue Agency & 2004 \\
Golden-Picci Index & Index $^{22}$ & Interior Ministry \& ISTAT & 1997 \\
Special Commissioners & Golden and Picci (2005) & $1991-2005$ \\
\hline
\end{tabular}

Notes: ${ }^{1}$ Social cooperatives per 100,000 residents, provincial level. ISTAT: "Le cooperative sociali in Italia" (2006) and "Le organizzazioni di volontariato in Italia" (2005); 2001 general election, provincial level. Interior Ministry: "Archivio storico delle elezioni" http://elezionistorico.interno.it/ ; ${ }^{3}$ Books published, in absolute value, provincial level. ISTAT: "La produzione libraia" (2007); ${ }^{4}$ Purchased books over resident population, provincial level. Il Sole24Ore "Dossier sulla qualità della vita" (2004); ${ }^{5}$ Includes education, healthcare and leisure facilities, provincial level.Tagliacarne Institute "Atlante di competitività delle province italiane" (2001); ${ }^{6}$ Includes the following networks: roads, railroads, ports, airports, energy, ICT, banking, provincial level. Tagliacarne Institute "Atlante di competitività delle provincie italiane" (2001); ${ }^{7}$ Regional health deficit per capita 1997-2004, regional level. Elaboration on Ministry of Economy and Finance and Ministry of Health data from "Relazione generale sulla situazione economica del Paese" (1997-2004); ${ }^{8}$ Share of separate waste collection on total waste collection, provincial level. Tagliacarne Institute "Atlante di competitività delle province italiane" (2001); ${ }^{9}$ Includes 25 indexes relative to: air quality, water quality, purification plants, waste management, public transportation, energy consumption, Public parks, Eco management, provincial level. Legambiente "Ecosistema Urbano 2004" (2004); ${ }^{10}$ Import + Export on the gross domestic product, provincial level. Tagliacarne Institute "Atlante di competitività delle provincie italiane" (2001); ${ }^{11}$ Public servants over resident population, regional level. ISTAT: "Indicatori statistici sulle amministrazioni centrali e locali" (2003) http://dati.statistiche-pa.it/ ; ${ }^{12}$ Number of firms for 100 residents, provincial level. Tagliacarne Institute "Atlante di competitività delle province italiane" (2008); ${ }^{13}$ Firms registration/mortality, provincial level. Tagliacarne Institute "Atlante di competitività delle province italiane" (2003-2004); ${ }^{14}$ Includes 39 indexes relative to: entrepreneurship, job Market, tax system, market competition, banking, bureaucracy; public services to firms, firms' cooperation, provincial level. Confartigianato: "L'indice Confartigianato - Qualità della vita dell'impresa" (2009); ${ }^{15}$ Number of crimes against property over resident population, provincial level. ISTAT: "Indicatori territoriali per le politiche di sviluppo" (2003); ${ }^{16}$ Number of crimes reported over resident population, provincial level. ISTAT: "Indicatori territoriali per le politiche di sviluppo" (2003); ${ }^{17}$ Average length of judicial process, regional level.CRENOS "Data-base on crime and deterrence in the Italian regions (1970-1999)"; ${ }^{18} \mathrm{Number}$ of completed civil and criminal trials for magistrate, regional courts level. Ministry of Justice, statistics: "Graduatoria rispetto agli esauriti per magistrato presente" (2004-2008); ${ }^{19}$ ISTAT estimation, provincial level.ISTAT: "Le misure dell'economia sommersa secondo le statistiche ufficiali" (2003); ${ }^{20}$ Based on the difference between the estimated added value by national accounts and tax system (IRAP and individual income tax returns), provincial level. Agenzia delle entrate: "Analisi dell'evasione fondata su dati IRAP, Anni 1998-2002" (2006); ${ }^{21}$ Number of crimes against the public administration over number of public servants, regional level. ISTAT: "Indicatori territoriali per le politiche di sviluppo" (2004); ${ }^{22}$ Difference between the amounts of physically existing public infrastructure and the amounts of money cumulatively allocated by government to create these public works, provincial level. Golden and Picci (2005); ${ }^{23}$ Absolute value of the overruled municipalities on total municipalities, regional level. Interior Ministry: "Relazione sull'attività svolta dalla gestione straordinaria dei Comuni commissariati" (1991-2005).

Table 3A. The Institutional Quality Index of considered provinces in 2012.

\begin{tabular}{|c|c|c|c|c|c|c|c|}
\hline Province & IQI & Province & IQI & Province & IQI & Province & IQI \\
\hline Agrigento & 0.2135 & Firenze & 1 & Palermo & 0.1998 & Salerno & 0.5378 \\
\hline Alessandria & 0.6651 & Foggia & 0.3511 & Pavia & 0.6229 & Sassari & 0.4713 \\
\hline Ancona & 0.7505 & Forlì-Cesena & 0.7719 & Perugia & 0.7572 & Siena & 0.877 \\
\hline Aosta & 0.7469 & Genova & 0.5228 & Pesaro e Urbino & 0.7524 & Sondrio & 0.6969 \\
\hline Arezzo & 0.8635 & Gorizia & 0.775 & Pescara & 0.6235 & Taranto & 0.3795 \\
\hline Ascoli Piceno & 0.6794 & Grosseto & 0.7928 & Piacenza & 0.7435 & Teramo & 0.7788 \\
\hline Asti & 0.6614 & Imperia & 0.4221 & Pisa & 0.8757 & Terni & 0.7312 \\
\hline Avellino & 0.4538 & Isernia & 0.2001 & Pistoia & 0.7705 & Torino & 0.6823 \\
\hline Benevento & 0.5197 & La Spezia & 0.6083 & Pordenone & 0.703 & Trapani & 0.147 \\
\hline Bergamo & 0.7405 & Latina & 0.5209 & Potenza & 0.3976 & Trento & 0.873 \\
\hline Bologna & 0.695 & Lecce & 0.4937 & Prato & 0.8179 & Treviso & 0.7935 \\
\hline Bolzano/Bozen & 0.8553 & Lucca & 0.8504 & Ragusa & 0.2887 & Trieste & 0.7984 \\
\hline
\end{tabular}




\begin{tabular}{|c|c|c|c|c|c|c|c|}
\hline Brescia & 0.7029 & Macerata & 0.7209 & Ravenna & 0.8135 & Udine & 0.698 \\
\hline Brindisi & 0.4459 & Mantova & 0.729 & $\begin{array}{l}\text { Reggio di } \\
\text { Calabria }\end{array}$ & 0.0398 & Venezia & 0.7247 \\
\hline Cagliari & 0.3927 & Modena & 0.7035 & $\begin{array}{c}\text { Reggio } \\
\text { nell'Emilia }\end{array}$ & 0.7126 & Verona & 0.7312 \\
\hline Caserta & 0.411 & Novara & 0.7585 & Rieti & 0.5958 & Vicenza & 0.7186 \\
\hline Chieti & 0.8574 & Nuoro & 0.4515 & Rimini & 0.7645 & Viterbo & 0.5397 \\
\hline Cuneo & 0.8075 & Padova & 0.7308 & Roma & 0.7297 & & \\
\hline
\end{tabular}

Source: 9.

Table 4A. The average IQI at region level in 2012.

\begin{tabular}{|c|c|c|}
\hline Italian regions & $\begin{array}{c}\text { Italian macro- } \\
\text { area }\end{array}$ & Average IQI \\
\hline Trentino Alto Adige & Northern & 0.8642 \\
\hline Tuscany & Central & 0.8109 \\
\hline Abruzzo & Southern & 0.8020 \\
\hline Valle D'Aosta & Northern & 0.7469 \\
\hline Veneto & Northern & 0.7452 \\
\hline Emilia Romagna & Northern & 0.7436 \\
\hline Umbria & Central & 0.7396 \\
\hline Friuli Venzia Giulia & Northern & 0.7158 \\
\hline Lombardy & Northern & 0.7033 \\
\hline Piedmont & Northern & 0.7021 \\
\hline Marche & Central & 0.6955 \\
\hline Lazio & Central & 0.5831 \\
\hline Liguria & Northern & 0.5313 \\
\hline Campania & Southern & 0.5010 \\
\hline Apulia & Southern & 0.4374 \\
\hline Sardinia & Southern & 0.4214 \\
\hline Basilicata & Southern & 0.3976 \\
\hline Sicily & Southern & 0.2065 \\
\hline Molise & Southern & 0.2001 \\
\hline Calabria & Southern & 0.0398 \\
\hline Total & & 0.6898 \\
\hline
\end{tabular}

Source: our elaborations on data by Nifo and Vecchione (2014). 